\title{
PENGARUH FAKTOR BUDAYA, PSIKOLOGI, PELAYANAN, PROMOSI DAN PENGETAHUAN TENTANG PRODUK TERHADAP KEPUTUSAN NASABAH MEMILIH BPRS DI BANYUMAS
}

\author{
Ida Nurlaeli ${ }^{1}$ \\ ${ }^{1}$ Universitas Islam Negeri Semarang
}

\begin{abstract}
ABSTRAK
Tujuan penulisan makalah ini adalah untuk mengetahui apakah faktor budaya, psikologis, pelayanan, promosi dan pengetahuan tentang produk berpengaruh terhadap keputusan nasabah dalam memilih bank syari'ah. Dari hasil uji validitas dan reliabilitas, nilai Cronbach Alpha sebesar 0,911> 0,6 maka dapat disimpulkan bahwa variabel tersebut adalah valid dan reliabel untuk mengukur pengaruh budaya, psikologis, pelayanan, promosi, pengetahuan tentang produk terhadap keputusan nasabah dalam memilih bank syari'ah.
\end{abstract}

Hasil uji asumsi klasik, yang meliputi uji multikolinearitas dan uji heteroskedstisitas, bahwa hasil pengujian multikolinearitas, hasil perhitungan nilai tolerance tidak ada variabel independen yang memiliki nilai tolerance $<0,10$. Demikian juga dengan hasil perhitungan nilai VIF, dari variabel independen yang diuji tidak ada nilai VIF yang lebih dari 10, maka tidak ada multikolinearitas antara variabel independen dalam model regresi. Hasil pengujian heteroskedastisitas, Hasil grafik Scatterplot yang tersaji memperlihatkan bahwa titik-titik menyebar secara acak serta tersebar di atas maupun di bawah angka 0 pada sumbu y, serta tidak mempunyai pola yang jelas atau tidak membentuk suatu pola, maka tidak terjadi heteroskedastisitas pada model regresi, sehingga model regresi layak digunakan sebagai alat prediksi.

Hasil uji hipotesis dengan regresi berganda, tingkat signifikan untuk variabel budaya sebesar 0,531>0,05, artinya variabel budaya secara parsial tidak berpengaruh nyata terhadap keputusan nasabah memilih bank syariah. Tingkat signifikasi variabel psikologi $0,824>0,05$ yang berarti variabel psikologis secara parsial tidak berpengaruh nyata terhadap keputusan nasabah memilih bank syariah. Tingkat signifikasin variabel pelayanan $0,000<0,05$ yang berarti variabel pelayanan secara parsial berpengaruh positif terhadap keputusan nasabah dalam memilih bank syariah. Tingkat signifikasi variabel promosi $0,000<0,05$ yang berarti variabel promosi secara parsial berpengaruh posotif terhadap keputusan nasabah dalam memilih bank syariah. Tingkat signifikasi variabel pengetahuan tentang produk $0,012<0,05$ yang berarti variabel pengetahuan tentang produk secara parsial berpengaruh positif terhadap keputusan nasabah memilih bank syariah. 


\section{Islãmadîna}

Ada tiga variabel yang nilai signifikannya dibawah 0.05 , yaitu variabel dengan nilai pelayanan, promosi dan pengetahuan tentang produk. Hal ini menunjukkan bahwa ketiga variabel tersebut berpengaruh signifikan terhadap keputusan nasabah dalam memilih bank syariah.

Kata kunci : Budaya, Psikologi, Pelayanan, Promosi, Pengetahuan, Produk, Keputusan 


\section{ABSTRACT \\ INFLUENCE OF CULTURAL FACTORS, PSYCHOLOGY, SERVICES, PROMOTION AND KNOWLEDGE OF PRODUCTS ON DECISION OF THE CUSTOMER SELEMS BPRS IN BANYUMAS}

The purpose of this paper is to find out whether the cultural, psychological, service, promotion and knowledge of the product affect the decision of customers in choosing a bank Shariah. From result of validity and reliability test, Cronbach Alpha value 0,911>0,6 it can be concluded that the variable is valid and reliable to measure cultural, psychological, service, promotion, knowledge about product to customer decision in choosing syariah bank.

The results of the classical assumption test, which includes multicollinearity test and heteroskedstisitas test, that the results of multicolinearity testing, the calculation of tolerance values there is no independent variable that has a tolerance value $<0.10$. Similarly, the VIF value calculation results, from independent variables tested there is no VIF value more than 10, then there is no multicollinearity between independent variables in the regression model. Result of heteroscedasticity test, Scatterplot graphic results presented show that the points spread randomly and spread over and below the number 0 on the $y$-axis, and does not have a clear pattern or do not form a pattern, then there is no heteroskedastisitas on the regression model, so the regression model deserves to be used as a predictor.

The result of hypothesis test with multiple regression, significant level for culture variable is $0,531>0,05$, it means partial culture variable have no significant effect to customer decision to choose syariah bank. The significance level of psychological significance is $0.824>0,05$, which means that psychological variables partially have no significant effect on customer decision to choose sharia bank. The significance level of service variable is $0,000<0,05$, which means partial service variable have positive effect to customer decision in choosing syariah bank. Level of promotion variable significance $0.000<0,05$ meaning partial promotion variable posotif influence to customer decision in choosing syariah bank. Level of significance variable significance knowledge about product $0,012<0,05$ meaning variable of knowledge about product partially have positive effect to customer decision to choose syaria bank. There are three variables whose significance value is below 0.05 , that is variable with value of service, promotion and knowledge about product. This shows that the three variables have a significant effect on customer decisions in choosing Islamic banks.

Keywords: Culture, Psychology, Service, Promotion, Knowledge, Product, Decision 


\section{Islãmadîna \\ JURNAL PEMIKIRAN ISLAM}

\section{PENDAHULUAN}

BPRS adalah salah satu lembaga keuangan perbankan syariah, yang pola operasionalnya mengikuti prinsip-prinsip syariah ataupun muamalat islam (Ifham, Ahmad, 2010: 3). Dalam Undang-Undang Nomor 21 Tahun 2008 menyebutkan bahwa Bank Pembiayaan Rakyat Syari'ah (BPRS) yaitu Bank Syari'ah yang dalam kegiatannya tidak memberikan jasa dalam lalu lintas pembayaran (Umam, Khotibul, 2009: 41). Market share lembaga keuangan non perbankan khususnya BPRS dan perbankan syari'ah tingkat daerah menunjukkan perkembangan yang lebih bagus, sebagai contoh, Dana Pihak Ketiga (Funding) dan Lending (pembiayaan/kredit) Bank Umum Konvensional dan Bank Umum Syari'ah di Banyumas:

Tabel 1.

\begin{tabular}{ccccc}
\hline \multirow{2}{*}{ Tahun } & \multicolumn{2}{c}{ Bank Umum Konvensional } & \multicolumn{2}{c}{ Bank Umum Syari'ah } \\
\cline { 2 - 5 } & Funding & Lending & Funding & Lending \\
2010 & $\%$ & $\%$ & $\%$ & $\%$ \\
2011 & 97.44 & 95.87 & 2.56 & 4.13 \\
2012 & 96.66 & 93.37 & 3.34 & 6.63 \\
2013 & 95.75 & 93.68 & 4.25 & 6.32 \\
2014 & 95.31 & 93.72 & 4.69 & 6.28 \\
\hline
\end{tabular}

Data Bank Indonesia (BI ) Cabang Purwokerto

Dana Pihak Ketiga (Funding) dan Lending (pembiayaan/kredit) BPR dan BPRS di Banyumas:

Tabel 2.

\begin{tabular}{ccccc}
\hline \multirow{2}{*}{ Tahun } & \multicolumn{2}{c}{ BPR } & \multicolumn{2}{c}{ BPRS } \\
\cline { 2 - 5 } & Funding & Lending & Funding & Lending \\
2011 & $\%$ & $\%$ & $\%$ & $\%$ \\
2012 & 92.77 & 92.14 & 7.23 & 7.86 \\
2013 & 91.62 & 91.28 & 8.38 & 8.72 \\
2014 & 90.53 & 90.71 & 9.48 & 9.29 \\
\hline
\end{tabular}

Data OJK (Otoritas Jasa Keuangan) Cabang Purwokerto

Dari data di atas market share Perbankan syari'ah di Banyumas baik funding (5.21\%) maupun pembiayaan (5.72\%) menunjukkan hasil prosentase yang lebih besar daripada market share perbankan syari'ah secara nasional (5\%), demikian juga market share BPRS. Bahkan market share BPRS menunjukkan prosentase yang lebih besar daripada market share Bank Umum Syari'ah baik funding nya yang mencapai $9.86 \%$ maupun pembiayaannya yang mencapai $9.97 \%$.

Berdasarkan latar belakang diatas, maka peneliti tertarik untuk melakukan penelitian tentang pengaruh budaya, psikologis, pelayanan, promosi dan 
pengetahuan tentang produk terhadap keputusan memilih bank syari'ah di BPRS se-Banyumas. Oleh karena itu peneliti akan melakukan penelitian dengan judul "Pengaruh Budaya, Psikologis, Pelayanan, Promosi, dan Pengetahuan Tentang Produk Terhadap Keputusan Memilih Bank Syariah di BPRS se-Banyumas".

\section{Keputusan Pembelian}

Pengambilan keputusan merupakan proses penilaian dan pemilihan berbagai alternatif sesuai kepentingan dengan menetapkan pilihan yang dianggap menguntungkan (Amirullah: 2002, 61). Pengambilan keputusan membutuhkan beberapa langkah yang terdapat dalam pikiran seseorang dan sekaligus mengajaknya berpikir sistematis (Salusu: 1994,47). Dalam mengambil keputusan seorang dihadapkan pada kondisi tidak pasti maksudnya faktor yang diharapkan mempengaruhi dan memiliki kadar informasi sangat rendah, jangka panjang, maksudnya implikasinya memiliki jangkauan yang jauh dan melibatkan sumber usaha yang penting, adapun kompleks dalam preferensi pengambilan keputusan atas resiko dan waktu memiliki peranan yang besar (Marimin: 2004,10).

Proses pengambilan keputusan ada yang sederhana dan ada pula yang kompleks, menurut Hawkins et al. (1992) dan engel et al. (1990) pengambilan keputusan ada tiga jenis yaitu ( Tjiptono, Fandy: 2008, 20-21): 1) Proses pengambilan keputusan yang luas, merupakan jenis keputusan yang lengkap yang bermula dari pengenalan masalah konsumen yang dapat dipecahkan melalui pembelian beberapa produk, 2) Proses pengambilan keputusan terbatas, terjadi apabila konsumen mengenal masalahnya, kemudian mengevaluasi beberapa alternatif produk atau merk berdasarkan pengetahuan yang dimiliki tanpa berusaha mencari informasi baru tentang produk atau merk tersebut, 3) Proses pengambilan keputusan yang bersifat kebiasaan, dimana konsumen mengenal masalahnya kemudian langsung mengambil keputusan untuk membeli merk kegemarannya.Ada lima tahap yang dilalui konsumen dalam proses pembelian yaitu, pengenalan masalah kebutuhan, pencarian informasi, evaluasi alternatif, keputusan pembelian dan perilaku pasca pembelian.

\section{Gambar 1.}

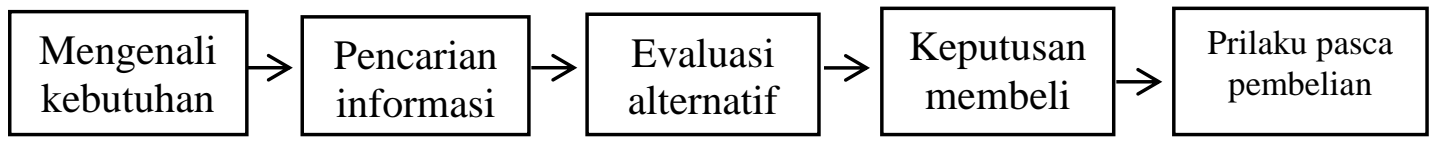

Sumber: (Setiadi, Nugroho: 2003, 16) 


\section{Islãmadîna \\ JURNAL PEMIKIRAN ISLAM}

Ket: Gambar 1 menyiratkan bahwa pembeli/nasabah melalui 5 tahap sebelum memutuskan memilih yakni tahap pengenalan, pencarian informasi, evaluasi alternatif, membeli, hasil.

\section{Faktor yang Mempengaruhi Pengambilan Keputusan}

\section{Budaya}

Dalam prespektif Islam budaya adalah segala nilai, pemikiran, serta simbol yang mempengaruhi perilaku, sikap, kepercayaan, serta kebiasaan seseorang dan masyarakat. Contohnya adalah budaya tepat waktu yang diajarkan dalam Islam. Dalam hadits riwayat Imam Baihaqi, Rosulullah SAW bersabda yang artinya "Siapkan lima sebelum (datangnya) lima. Masa hidupmu sebelum datang waktu matimu, masa sehatmu sebelum datang waktu sakitmu, masa senggangmu sebelum datang masa sibukmu, masa mudamu sebelum datang masa tuamu, dan masa kayamu sebelum datang masa miskinmu." (HR Baihaqi dari Ibnu Abbas)". (Sobirin, 2007:50)

Dalam konteks perkembangan kebudayaan Jawa, Banyumas dipandang sebagai wilayah marginal (Koentjaraningrat, 1984) yang berkonotasi kasar, tertinggal dan tidak lebih beradab dibanding dengan kebudayaan yang berkembang di wilayah negarigung (pusat kekuasaan kraton) yang dijiwai oleh konsep adiluhung. Hal ini disebabkan kondisi dan letak geografis Banyumas yang jauh dari pusat kekuasaan kraton serta latar belakang kehidupan dan pandangan hidup masyarakat Banyumas yang dijiwai oleh semangat kerakyatan, mengakibatkan pada berbagai sisi budaya Banyumas dapat dibedakan dari budaya induknya.

Persebaran agama Islam di Banyumas memberikan pengaruh yang cukup kuat terhadap pertumbuhan kebudayaan di daerah itu. Agama Islam mulai menyebar di wilayah Banyumas berlangsung sejak era Demak, yaitu pada saat wilayah ini di bawah kekuasaan Kadipaten Pasir. Pembawa ajaran agama Islam adalah Makdum Wali, yang berhasil mengislamkan Adipati Banyak Blanak. Persebaran Islam di Banyumas tidak serta-merta menghilangkan kepercayaan lama yang telah berakar dalam kehidupan masyarakat di wilayah ini. Islam yang dikembangkan di wilayah ini berupa Islam Abangan yang tetap memberikan peluang bagi berkembangnya kepercayaan animisme-dinamisme bagi pemeluknya.

BPRS merupakan lembaga keuangan syariah yang secara geografis berada di pinggiran kota dan didominasi oleh nasabah yang berasal dari pedesaan, maka budaya yang dimaksud dalam penelitian ini adalah budaya yang 
banyak dianut oleh nasabah BPRS yakni "budaya membingkai agama". Aspek-aspek kebudayaan berperan lebih dominan dalam kehidupan sosial, membingkai ajaran-ajaran Islam yang menghasilkan Islam Abangan, contoh pemahaman tentang ketuhanan dibingkai dalam nuansa budaya lokal seperti dapat dijumpai dalam ragam kesenian, ungkapan tradisional, folklore, kepercayaan tradisional dan lain-lain. Dalam penelitian Abdurrahman M, diantara bentuk akulturasi budaya lokal (Jawa) khususnya budaya Banyumas dengan Islam contohnya adalah tradisi yang dianut oleh komunitas Islam Aboge. Komunitas ini melaksanakan tradisi-tradisi Jawa dengan dibumbui tradisi Islam, maka munculah Islam dengan cita rasa lokal (Islam Lokal). Kekhasan dari komunitas ini adalah masih digunakannya model Penanggalan Islam Jawa (Penanggalan Aboge (Alip Rebo Wage)) untuk menetapkan awal Ramadhan, Hari raya Idhul Fitri dan Idhul Adha. Penggunaan penanggalan ini mengakibatkan ibadah puasa, perayaan Idhul Fitri dan Idhul Adha yang mereka rayakan selalu berbeda dengan apa yang telah ditetapkan oleh pemerintah. (Abdurrahman M, 2012: 1)

Penelitian yang dilakukan oleh Pandu Wicaksono kaitannya dengan bermasyarakat dan menjalankan kegiatan ekonomi yang dilakukan oleh masyarakat Aboge adalah menjaga toleransi keagamaan dengan masyarakat sekitar dengan cara saling menghormati dan menjunjung tinggi nilai-nilai toleransi dalam kehidupan bermasyarakat, berbangsa, dan bernegara. Dan untuk mengantisipasi terjadinya konflik horizontal, yaitu dengan berbagai macam kegiatan yang bersifat positif seperti: dalam hal keagamaan, hal pemerintahan, hal perekonomian, dan hal sosial kemasyarakatan. (Pandu Wicaksono, t.th: 2)

\section{Psikologis}

Beberapa ahli beranggapan bahwa perilaku konsumen dipengaruhi oleh dorongan psikologis dan teori-teori ini terbagi dalam 2 (dua) bagian besar yaitu teori Pembelajaran dan teori Motivasi. Pavlov, Skinner dan Hull mengembangkan Teori Pembelajaran yang menyatakan bahwa perilaku seseorang merupakan hasil belajar akumulasi pengalaman selama hidupnya, maka pemasar perlu menciptakan komunikasi informal (word-of-mouth communication) yang positif tentang produk. Freud mengembangkan teori motivasi yang menyatakan seseorang tidak bisa memahami motivasi yang mendorong perilakunya secara pasti dan menurut Maslow bahwa motivasi seseorang dapat dihubungkan dengan kebutuhannya (Simamora, 2008: 8). Faktor psikologis lain yang dapat mempengaruhi keputusan konsumen antara lain: a) Persepsi yakni proses pemilihan, pengorganisasian, dan 


\section{Islãmadîna

penginterpretasian masukan informasi untuk menghasilkan makna, b) Sikap merujuk pada pengetahuan dan perasaan positif atau negatif terhadap sebuah obyek atau kegiatan tertentu dan c) Kemampuan dan pengetahuan, kemampuan merupakan kesanggupan dalam melakukan tugas tertentu, sedangkan pengetahuan merupakan aspek lain dari kemampuan seorang individu.

BPRS didominasi oleh nasabah yang memiliki cukup pembelajaran dan pengalaman tentang ekonomi syariah, dilihat dari golongan terdiri dari golongan menengah (middle class) dan golongan bawah (low class), kebutuhan yang mereka miliki menjadi motivasi tersendiri bagi nasabah untuk melakukan transaksi dengan BPRS. Penelitian Atin Yulaifah menghasilkan bahwa variabel budaya, sosial, pribadi dan psikologi secara bersama-sama atau simultan mempengaruhi keputusan nasabah dalam memilih bank syari'ah dengan nilai $F_{\text {hitung }}(29,228)>F_{\text {tabel }}(2.467)$, secara parsial variabel pribadi dan psikologi berpengaruh secara signifikan, variabel budaya dan sosial tidak berpengaruh signifikan, dan dari hasil uji regresi berganda variabel psikologi merupakan variabel yang dominan pengaruhnya terhadap keputusan nasabah dalam memilih bank syari'ah.

\section{Pelayanan}

Pelayanan adalah proses pemenuhan kebutuhan melalui aktivitas orang lain secara langsung. Pelayanan yang diperlukan manusia secara umum dikelompokan dua jenis, yaitu layanan fisik yang sifatnya pribadi sebagai manusia dan layanan administratif yang diberikan oleh orang lain selaku anggota organisasi, baik itu organisasi massa atau negara. Dalam rangka mempertahankan hidupnya, manusia sangat memerlukan pelayanan, baik dari diri sendiri maupun melalui karya orang lain.(Moenir dalam Nogi, 2005 : hal. 208)

Service are those separately identifiable, essentially, intangible activites that provide want-satisfaction and that are not necessarily tied to the sale of a product or another service. To produce a service may or may nor require the use of tangible goods". (Stanton dalam Alma, 2004). Jasa dapat diidentifikasi secara terpisah, tidak berwujud, ditawarkan untuk memenuhi kebutuhan. Jasa dapat dihasilkan dengan menggunakan benda-benda berwujud atau tidak.

Kualitas pelayanan adalah seberapa jauh perbedaan antara kenyataan dan harapan para pelanggan atas layanan yang mereka terima (Ahmad Guspul, 2014:158). Kualitas pelayanan dapat diketahui dengan cara membandingkan 
persepsi para pelanggan atas layanan yang benar-benar mereka terima.

Tjiptono \& Chandra (2005), kualitas pelayanan merupakan ukuran seberapa baik tingkat layanan yang diberikan mampu sesuai dengan harapan pelanggan. Sedangkan menurut Tjiptono (2001), kualitas pelayanan adalah tingkat keunggulan yang diharapkan dan pengendalian atas tingkat keunggulan tersebut untuk memenuhi keinginan pelanggan.

Penelitian yang dilakukan oleh tim yang terdiri dari Dr. Hanif Amali Rivai, SE. MSi, Dr. Niki Lukviarman, MBA., Akt., Syafrizal, SE.ME., Drs. Syukri Lukman, MSi., Ferry Andrianus, SE.Msi., Drs. Masrizal, M.Soc.Sc. bahwa faktor pelayanan berupa keramahan petugas dan faktor psikologi berupa persepsi, berpengaruh dengan mengikuti faktor keyakinan tentang bunga bank bertentangan dengan agama. Lokasi yang dekat dan persyaratan yang lebih ringan juga berpengaruh besar, sedangkan varian produk yang ditawarkan bukan merupakan pertimbangan utama.

\section{Promosi}

Promosi terdiri dari beberapa tindakan antara lain; priklanan, promosi penjualan, penjualan pribadi, hubungan masyarakat dan pemasaran langsung (Maisya, hal 4). Beberapa perubahan paradigma strategi promosi sebagai dampak dari pengaruh perubahan tekhnologi (Rangkuti, 2009: 4):

Tabel 3

\begin{tabular}{lll}
\hline Faktor Promosi & Dahulu & Sekarang \\
\hline Target audience & masal & user \\
Frekuensi pembelian & sekali & berulang \\
Saluran distribusi & diler & langsung \\
R \& D & innovation & Joint venture \\
Differentiate by & technology & brand \\
Driving force & engineering & Customer needs \\
Orientasi perusahaan & Manufacturing/engineering & Brand marketing \\
Public relation & mengarahkan & Membina relationship \\
Komunikasi & Satu arah & Dua arah (dialog) \\
Prilaku konsumen & Social pressure & individualistic \\
Kualitas & Styling, short life & Real quality, long life \\
Geographic scape & national & Local and segmented \\
Jenis komunikasi & verbal & visual \\
Tingkat persaingan & moderate & agressive \\
Production run & simple & Complex \& customized \\
Jenis media komunikasi & Dominasi TV dan koran & Multimedia, integrated \\
& & marketing communication \\
Appeal & Features dan benefits & Symbols, metaphors dan \\
& & karakter \\
\hline
\end{tabular}


Menurut penelitian Muladi faktor sistem bagi hasil, persyaratan administrasi, kualitas pelayanan, sistem operasional syari'ah dan promosi secara bersama-sama berpengaruh terhadap keputusan menjadi nasabah.

\section{Pengetahuan tentang Produk}

Himpunan bagian dari informasi total yang relevan dengan fungsi konsumen di dalam pasar disebut pengetahuan konsumen. Berdasarkan pengertian dari beberapa ahli diatas, pengetahuan konsumen adalah semua informasi yang dimiliki konsumen mengenai berbagai macam produk dan jasa, serta pengetahuan lainnya yang terkait dengan produk dan jasa tersebut dan informasi yang berhubungan dengan fungsinya sebagai konsumen. Pengetahuan konsumen akan mempengaruhi keputusan pembelian.

Menurut Sumarwan dalam situs Michiels (2013) membagi pengetahuan konsumen ke dalam tiga jenis pengetahuan, yaitu: (1)Pengetahuan produk yakni kumpulan berbagai informasi mengenai produk (produk, merek, terminologi produk, atribut atau fitur produk, harga produk dan kepercayaan mengenai produk). Pengetahuan produk meliputi; Pengetahuan tentang karakteristik atau atribut produk, Pengetahuan tentang manfaat produk dan Pengetahuan tentang kepuasan yang diberikan produk bagi konsumen. (2)Pengetahuan pembelian adalah dimana membeli produk dan kapan membelinya. Perilaku membeli memiliki uratan store contact (mencari outlet, pergi ke outlet dan memasuki outlet), product contact (mencari lokasi produk, mengambil dan membawa produk ke kasir), transaction (membayar). (3)Pengetahuan pemakaian manfaat suatu produk dapat dirasakan setelah suatu produk dikonsumsi. Agar mendapatkan manfaat yang maksimal dan kepuasaan yang tinggi, maka produsen perlu mencantumkan saran penggunanaan atau pemakaian suatu produk sehingga produk berfungsi dengan baik.

\section{Kerangka Konseptual dan Hipotesis Penelitian}

Keputusan nasabah dalam memilih bank syari'ah dipengaruhi oleh banyak faktor, baik faktor internal berupa faktor psikologi, pengetahuan tentang produk, maupun faktor eksternal berupa faktor budaya, pelayanan dan promosi. Hal ini dapat dijelaskan dalam gambar di bawah ini: 
Gambar 2.

$(\mathbf{X})$

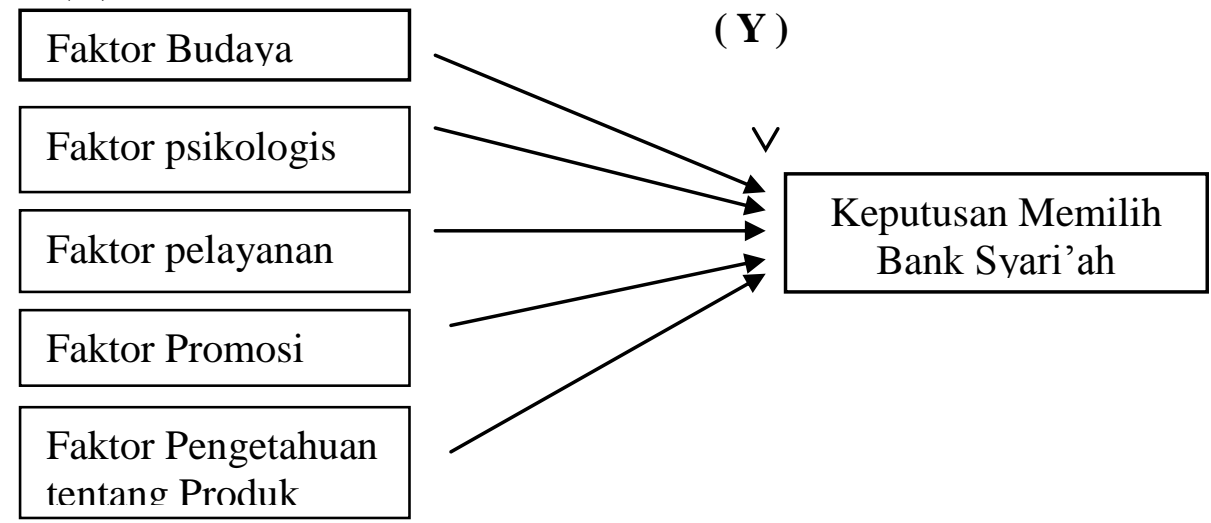

Ket: Gambar 2 menunjukkan kerangka konseptual pada penelitian ini, yang terdiri dari 5 variabel bebas yakni budaya, psikologis, pelayanan, promosi dan pengetahuan tentang produk dan keputusan memilih bank syari'ah sebagai variabel terikat.

Dengan demikian peneliti mengemukakan 5 hipotesis berdasar kerangka konseptual untuk menguji pengaruh setiap variabel bebas terhadap variabel terikat. Adapun rumusan hipotesis penelitian sebagai berikut:

$\mathrm{H}_{1}$ : Budaya berpengaruh negatif terhadap keputusan nasabah dalam memilih bank syariah

$\mathrm{H}_{2}$ :Psikologis berpengaruh negatif terhadap keputusan nasabah dalam memilih bank syariah.

$\mathrm{H}_{3}$ : Pelayanan berpengaruh positif terhadap keputusan nasabah dalam memilih bank syariah.

$\mathrm{H}_{4}$ : Promosi berpengaruh positif terhadap keputusan nasabah dalam memilih bank syariah.

$\mathrm{H}_{5}$ :Pengetahuan tentang produk berpengaruh positif terhadap keputusan nasabah dalam memilih bank syariah.

\section{METODE PENELITIAN}

\section{Jenis Penelitian}

Jenis penelitian ini adalah penelitian kuantitatif atau penelitian survey yang akan menggunakan kuesioner sebagai instrumen penelitian. Menurut Sugiyono metode ini menggunakan data penelitian yang berupa angka-angka dan analisis yang menggunakan statisitik dan menghasilkan interpretasi data (Prasetyo, Bambang dan Miftahul Janah, Lina, 2006: 49). Survei akan dilakukan ke BPRS dan nasabah BPRS. Sumber data primer merupakan data 
yang diperoleh dari sumber pertama seperti hasil wawancara atau hasil pengisian kuesioner, sedangkan data sekunder merupakan data primer yang telah diolah lebih lanjut dan disajikan, atau dari pendukung lainnya baik dalam bentuk tabel, atau diagram (Umar, Husein: 1997,9).

\section{Populasi dan Sampel}

Populasi dalam penelitian ini yakni nasabah BPRS, Populasi bukan hanya orang tetapi populasi juga berbentuk wilayah generasi yang terdiri atas: obyek/subyek yang mempunyai kualitas dan karakter tertentu yang ditetapkan oleh peneliti untuk dipelajari dan ditarik kesimpulan. Tekhnik pengambilan sampling dalam penelitian ini dengan metode stratified sampling. Artinya populasi dibagi terlebih dahulu menjadi beberapa kelompok dari setiap BPS, dan diambil secara random. Penentuan jumlah sampel menggunakan rumus Slovin :

$$
\begin{aligned}
& \mathrm{n}=\mathrm{N} /\left(1+\mathrm{N} \mathrm{e}^{2}\right) \\
& \text { Keterangan: } \\
& \mathrm{N}=\text { Jumlah populasi } \\
& \mathrm{n} \quad=\text { Jumlah sampel } \\
& \mathrm{e}=\text { Tingkat kesalahan }
\end{aligned}
$$

\section{Tekhnik pengumpulan data}

Pengumpulan data pada penelitian ini dilakukan dengan cara:

a. Wawancara, dilakukan kepada para nasabah BPRS

b. Kuesioner/angket untuk mengetahui kenyataan yang terjadi di lapangan.

Daftar pertanyaan berisi hal-hal yang menyangkut faktor budaya, psikologi, pelayanan, promosi dan pengetahuan nasabah tentang produk.

\section{Skala Pengukuran}

Jenis skala yang digunakan dalam penelitian ini adalah Skala Linkert. Skala Linkert adalah skala yang digunakan untuk mengukur sikap, pendapat dan persepsi seseorang atau kelompok orang tentang fenomena sosial. Dalam penelitian, fenomena sosial ditetapkan secara spesifik oleh peneliti, yang selanjutnya disebut dengan variabel penelitian (Sugiyono : 2012). Dengan skala likert, variabel yang diukur dijabarkan menjadi indikator variabel. Kemudian indikator tersebut dijadikan sebagai titik tolak untuk menyusun item-item instrumen yang dapat berupa pernyataan maupun pertanyaan. Skala likret menggunakan lima skala dengan tingkat dari yang sangat tidak setuju sampai setuju dimana responden nantinya hanya memilih satu jawaban diantara kelima skala tersebut: sangat setuju nilai skor $=5$, setuju 
nilai skor $=4$, ragu-ragu nilai skor $=3$, tidak setuju nilai skor $=2$, dan sangat tidak setuju nilai skor $=1$

\section{Variabel dan operasional variabel}

a. Variabel Independen ( X )

Variabel independen sering disebut variabel bebas dimana variabel bebas adalah variabel yang mempengaruhi dan menjadi sebab perubahan atau timbulnya variabel dependen (terikat) (Sugiyono, 2014: 64). Variabel independen dalam penelitin ini adalah faktor budaya, faktor psikologis, faktor pelayanan, faktor promosi, dan faktor pengetahuan tentang produk.

b. Variabel Dependen ( Y )

Variabel dependen disebut variabel output, kriteria konsekuen atau variabel terkait dimana variabel terkait merupakan variabel yang dipengaruhi atau menjadi akibat, karena adanya variabel bebas. (Sugiyono, 2013: 39). Variabel dependen adalah keputusan memilih bank syariah.

c. Definisi Operasional Variabel

Tabel 4.

\begin{tabular}{ll}
\hline Variabel Dependen $(\mathrm{Y})$ & Definisi Operasional dan Pengukuran \\
\hline Pengambilan keputusan & $\begin{array}{l}\text { Pengambilan keputusan (kptsn) merupakan proses } \\
\text { penilaian dan pemilihan berbagai alternatif sesuai } \\
\text { memilih bank syariah }\end{array}$ \\
$\begin{array}{l}\text { kepentingan dengan menetapkan pilihan yang dianggap } \\
\text { menguntungkan. }\end{array}$
\end{tabular}

Variabel Independen (X)

Faktor Budaya

Faktor Budaya (Bud) merupakan nilai, pemikiran dan simbol yang mempengaruhi perilaku, sikap, kepercayaan dan kebiasaan seseorang.

Faktor Psikologi

Faktor Psikologis (Psi) merupakan keadaan yang timbul dari kondisi fisiologis, dipengaruhi oleh pembelajaran dan motivasi.

Faktor Pelayanan

Faktor Pelayanan (Plyn) merupakan pemenuhan kebutuhan melalui aktivitas orang lain secara langsung melalui layanan fisik yang sifatnya pribadi dan layanan administratif.

Faktor Promosi $\quad$ Faktor Promosi (Prmsi) merupakan komunikasi pemasaran baik dengan iklan, brosur, hubungan masyarakat, penjualan personal yang digunakan perusahaan untuk mengkomunikasikan dan membangun hubungan dengan pelanggan. 


\section{Islãmadîna \\ JURNAL PEMIKIRAN ISLAM}

Volume XVIII, No. 2, Juni 2017 : 75-106

\begin{tabular}{ll}
\hline Faktor Pengetahuan & Faktor pengetahuan tentang Produk (Peng) merupakan \\
Tentang Produk & pengetahuan nasabah tentang karakteristik atau atribut \\
& produk, manfaat produk dan kepuasan yang diberikan \\
& produk terhadap nasabah. \\
\hline
\end{tabular}

\section{Tekhnik Analisis Data}

Sebelum data-data dianalisis untuk menjawab hipotesis, terlebih dahulu akan diuji keabsahan/kelayakan datanya. Uji-uji tersebut terdiri dari Uji Validitas, Uji Reliabilitas dan Uji Asumsi Klasik

a. Uji Validitas

Uji validitas, keadaan yang mampu menggambarkan tingkat instrumen yang bersangkutan mampu mengukur apa yang akan diukur (Tukiran dan Hidayat: 2011, 42). Uji validitas digunakan untuk mengetahui kelayakan butir-butir dalam suatu daftar pertanyaan atau pernyataan. Validitas, menunjukkan sejauh mana suatu alat pengukur itu mampu mengukur apa yang ingin diukur. Dengan kata lain mampu memperoleh data yang tepat dari variabel yang akan diteliti. Uji validitas dalam penelitian ini dilakukan dengan menggunakan analisis, yang menghitung koefisien korelasi antara skor item dengan skor totalnya, dengan menggunakan prosedur statistik person's product moment correlation. Jika butir pertanyaan itu valid maka terdapat (*) pada person's product moment correlation. Biasanya syarat minimum yang dapat memenuhi syarat adalah jika $\mathrm{r}<0,3$. Sehingga apabila ada korelasi dengan skor total kurang dari 0,3, maka butir dalam instrumen tersebut dikatakan tidak valid (Sugiyono: 2006, 267).

b. Uji Reliabilitas

Uji reliabilitas, suatu instrumen cukup dapat dipercaya untuk digunakan sebagai alat pengumpul data karena instrumen tersebut sudah baik, dapat dipercaya dan dapat menghasilkan data yang di percaya juga. Uji reliabilitas dapat dilakukan dengan cara tes ulang (retest) yakni dengan cara penggunaan instrumen tersebut terhadap subjek yang sama, dilakukan dalam waktu yang berlainan (Taniredja, Tukiran dan Hidayati: 2011, 43). Menurut (Umar, Husein: 2002, 135) reliabilitas adalah suatu angka indeks yang menunjukan konsistensi suatu alat pengukur dalam mengukur gejala yang sama. Setiap alat pengukur seharusnya memiliki kemampuan untuk memberikan hasil pengukuran yang konsisten. Uji ini digunakan untuk menguji seberapa konsisten satu atau seperangkat pengukuran mengukur suatu konsep yang diukur. Reliabilitas instrumen 
dilihat dari Cronbach Alpa. Suatu konstruk atau variabel dikatakan reliabel jika nilai Cronbach Alpa > 0,6 (Ghozali, Imam: 2001,42).

c. Uji Asumsi Klasik, yang terdiri dari Uji Multikolinearitas dan Uji Heterokedastisitas

1) Uji Multikolinearitas

Dalam permasalahan regresi linier berganda selain dilakukan uji di atas, juga perlu diadakan pengujian yang berkaitan dengan multikolinearitas, dikarenakan hal tersebut dapat mempengaruhi bias tidaknya kesimpulan suatu analisa regresi berganda. Multikolinearitas adalah kejadian yang menginformasikan terjadinya hubungan antara variabel-variabel bebas an hubungan yang terjadi cukup besar. Hal ini akan menyebabkan perkiraan keberartian koefisien regresi yang diperoleh. Untuk mengetahui ada atau tidaknya multikolinearitas dalam model regresi yaitu dengan melihat toleransi variabel dan Variance Inflation Factor (VIF)

2) Uji Heterokedastisitas

Heterokedastisitas tidak terjadi yakni jika tidak ada pola yang jelas serta titik-titik menyebar di bawah angka 0 pada sumbu Y (Santoso, 2001), untuk mendeteksi apakah ada atau tidak gejala heterokedastisitas dapat dilakukan dengan uji Park yaitu dengan meregresikan hasil logaritma pengkuadratan residual terhadap variabel independen (Ghozali, 2005) Heterokedastisitas dengan uji Park tidak terjadi apabila tidak satupun variabel independen signifikan secara statistik mempengaruhi variabel dependen nilai logaritma (In Ui2)

d. Uji Hipotesis, yang terdiri dari Uji $\boldsymbol{R}^{2}$, Uji F dan Uji t

\section{1) Uji $\boldsymbol{R}^{2}$}

Uji koefisien determinasi berguna untuk mengukur seberapa jauh kemampuan variabel bebas dalam merangkai variabel terikat, yaitu mengetahui seberapa besar variabel independen menjelaskan variabel dependen. Namun untuk regresi linear berganda sebaiknya menggunakan $\mathrm{R}$ square yang telah disesuaikan atau tertulis Adjusted $R$ square, karena telah disesuaikan dengan jumlah variabel independen yang digunakan dalam penelitian (Agung Nugroho, Bhuono: 2005, 51). Selain itu koefisien determinasi pada intinya mengukur seberapa jauh kemampuan model dalam menerangkan variasi variabel independen. 


\section{Islãmadîna

Nilai koefisien determinasi adalah antara 0 dan 1 . Nilai $R^{2}$ yang kecil berati kemampuan variabel independen dalam menjelaskan variasi variabel dependen amat terbatas. Nilai yang mendekati 1 berarti variabel independen memberikan hampir semua informasi yang dibutuhkan untuk memprediksi variasi variabel dependen. (Ghozali, 2011: 97).

2) $\mathrm{Uji} F$

Uji statistik $\mathrm{F}$ digunakan untuk mencari apakah semua variabel independen yang digunakan dalam model regresi secara bersama-sama berpengaruh terhadap variabel dependen (Priyanto, Dwi: 2011, 67). Hipotesis yang digunakan adalah:

a). $H_{0}: \beta_{1}, \beta_{2}, \beta_{3}=0$, variabel independen tidak berpengaruh secara bersama-sama terhadap variabel dependen.

b) $H_{1}: \beta_{1}, \beta_{2}, \beta_{3} \neq 0$, variabel independen berpengaruh secara bersama-sama terhadap variabel independen.

Pada tingkat signifikan 5 persen dengan kriteria pengujian yang digunakan berikut:

- $H_{0}$ ditolak dan $H_{1}$ diterima, apabila $\mathrm{F}$ hitung $>\mathrm{F}$ tabel, artinya variabel independen secara bersama-sama berpengaruh terhadap variabel dependen secara nyata.

- $H_{0}$ ditolak dan $H_{1}$ diterima, apabila $\mathrm{F}$ hitung $<\mathrm{F}$ tabel, artinya variabel independen secara bersama-sama tidak berpengaruh terhadap variabel dependen secara nyata.

3) Uji t

Uji t (parsial) bertujuan untuk mengetahui besarnya pengaruh masing-masing variabel independen secara individual (parsial) terhadap variabel dependen. Hipotesis yang digunakan adalah:

Menentukan $H_{0}$ dan $H_{1}$ :

- $H_{0}: H_{1}=0$, berarti tidak terdapat pengaruh yang nyata antara variabel independen dengan variabel dependen.

- $H_{0}: H_{1} \neq 0$, berarti terdapat pengaruh nyata antara variabel independen dengan variabel dependen 
Pada tingkat signifikan 5 persen dengan kritera pengujian yang digunakan sebagi berikut:

- Jika sig $>0,05$, maka $H_{1}$ diterima

- Jika sig $<0,05$, maka $H_{1}$ ditolak

\section{Model Analisis Data}

a. Regresi linear Berganda

Uji statistik regresi linear berganda digunakan untuk menguji signifikan atau tidaknya hubungan lebih dari dua variabel melalui koefisien regresinya (Hasan, Iqbal: 2004, 107). Regresi adalah suatu proses memperkirakan secara sistematis tentang apa yang paling mungkin terjadi dimasa yang akan datang berdasarkan informasi masa lalu dan masa kini agar kesalahannya dapat diperkecil (Ridwan, Engkos Achmad Kuncoro: 2008, 83). Analisis ini digunakan sebagai alat ukur untuk mengetahui seberapa besar tingkat pengaruh antara variabel independen $(\mathrm{X})$ dengan variabel dependen (Y). Metode ini juga bisa digunakan sebagai ramalan sehingga dapat diperkirakan baik dan buruknya suatu variabel $\mathrm{X}$ terhadap naik turunnya suatu tingkat variabe $\mathrm{Y}$ begitu juga sebaliknya (Yulaifah, Atin: 2011, 71). Untuk mengetahui regresi linear berganda digunakan rumus sebagi berikut:

$\mathrm{Y}=a+b_{1} X_{1}+b_{2} X_{2}+b_{3} X_{3}+b_{4} X_{4}+b_{5} X_{5}+e$

Ket: Y: keputusan nasabah dalam memimlih bank, $X_{1}$ : faktor budaya, $X_{2}$ : faktor psikologis, $X_{3}$ : faktor pelayanan, $X_{4}$ : faktor promosi, $X_{5}$ : pengetahuan tentang produk, $a$ : Intersip atau Koevisien, $b_{12345}$ : Koefisien Regresi, $e$ : Standar Error

Model Statistik

$$
\text { Kptsn }=b_{0}+b_{1} \text { Psi }+b_{2} \text { Bud }+b_{3} \text { Plyn }+b_{4} \text { Prmsi }+b_{5} \text { Peng }+e
$$

Keterangan: Kptsn: pengambilan keputusan nasabah, Psi: faktor psikologis, Bud: faktor budaya, Plyn: faktor pelayanan, Prmsi: faktor promosi, Peng: pengetahuan tentang prodak, e: Error Trem.

\section{HASIL DAN PEMBAHASAN}

1. Statistik deskriptif

Pengklasifikasian responden dalam penelitian ini bertujuan untuk mengetahui gambaran umum responden berdasar: 


\section{Islãmadîna \\ JURNAL PEMIKIRAN ISLAM}

a. Jenis kelamin

Tabel 5 .

\begin{tabular}{lc}
\hline Jenis Kelamin & Jumlah \\
\hline Perempuan & 43 \\
Laki-laki & 57 \\
\hline
\end{tabular}

Berdasarkan tabel di atas, responden dengan jenis kelamin laki-laki lebih dominan yaitu sebanyak 57 orang sedangkan responden berjenis kelamin perempuan sebanyak 43 orang.

b. Usia

Tabel 6.

\begin{tabular}{lc}
\hline Usia & Jumlah \\
\hline$<18$ Tahun & 5 \\
$18-25$ & 27 \\
$26-35$ & 17 \\
36 Tahun Keatas & 51 \\
\hline
\end{tabular}

Berdasarkan tabel di atas, usia responden yang paling dominan adalah usia 36 tahun keatas yaitu sebanyak 51 orang, diikuti usia responden 18-25 tahun sebanyak 27 orang, usia 26-35 sebanyak 17 orang, dan usia < 18 tahun sebanyak 5 orang. Nasabah yang yang berusia 36 tahun keatas lebih berpotensi melakukan investasi seperti menabung dan melakukan kegiatan perbankan lainnya di bank pembiayaan rakyat syariah Khasanah Ummat.

c. Pekerjaan

Tabel 7.

\begin{tabular}{lc}
\hline Pekerjaan & Jumlah \\
\hline Pelajar/Mahasiswa & 18 \\
Pengusaha/Wiraswasta & 78 \\
Pegawai Negeri & 4 \\
Guru/Dosen & 0
\end{tabular}

Berdasarkan tabel di atas, sebagian besar responden adalah pengusaha/wiraswasta dengan jumlah 78 orang, pelajar/mahasiswa sejumlah 18 orang, pegawai negeri sebanyak 4 orang dan tidak ada guru/dosen yang terlibat dalam penggunaan jasa di BPRS. Diketahui bahwa yang paling dominan adalah pengusaha/wiraswasta karena BPRS merupakan penggunaan jasa di bidang mikro yang didominasi oleh kalangan menengah kebawah. 
d. Pendapatan/gaji

\begin{tabular}{lc}
\multicolumn{2}{c}{ Tabel 8 } \\
\hline Pendapatan/Gaji & Jumlah \\
\hline$<1.000 .000$ & 25 \\
$1.000 .000-2.499 .999$ & 57 \\
$2.500 .000-4.999 .999$ & 15 \\
5.000 .000 Ke Atas & 3 \\
\hline
\end{tabular}

Berdasarkan tabel di atas diketahui bahwa 57 responden yang paling domina yang sebagian besar pendapatannya Rp 1.000.000 - 2.499.999 yang mampu menginvestasikan pendapatannya untuk menabung dan melakukan kegiatan perbankan lainnya. 25 responden dengan pendapatan sebesar $<1.000 .000$ juga mampu menginvestasikan pendapatanya untuk menabung dan melakukan kegiatan perbankan. Responden dengan jumlah 15 orang memiliki pendapatan sebesar Rp 2.500.000 - 4.999.999 juga mampu menginvestasikan pendapatannya untuk kegiatan menabung dan melakukan kegiatan lainnya di perbankan syariah, sedangkan pendapatan sebesar Rp 5.000.000 ke atas dengan jumlah nasabah 3 orang yang mampu menginvestasikan dananya untuk menabung dan melakukan kegiatan perbankan lainnya.

e. Pendidikan

Tabel 9.

\begin{tabular}{lc}
\hline Pendidikan Terakhir & Jumlah \\
\hline SMA & 75 \\
Diploma & 5 \\
S-1 & 7 \\
Lainnya, SMP & 13 \\
\hline
\end{tabular}

Dari hasil pengolahan kuesioner, tabel diatas menunjukkan sebagian besar responden adalah berpendidikan SMA dengan jumlah 75 responden, pendidikan SMP sejumlah 13 responden, berpendidikan S-1 sejumlah 7 responden dan pendidikan diploma sejumlah 5 responden. Bahwa sebagian besar nasabah berpendidikan SMA dikarenakan BPRS tidak menuntut nasabah yang berpendidikan tinggi untuk menggunakan jasa BPRS, namun siapa saja yang mampu menginvestasikan dana untuk menabung dan melakukan kegiatan perbankan syariah lainnya.

2. Hasil Uji Data

a. Hasil Uji Validitas Data

Uji validitas dalam penelitian ini dilakukan dengan menggunakan analisis, yang menghitung koefisien korelasi antara skor item dengan skor totalnya, dengan menggunakan prosedur statistik person's product moment 


\section{Islãmadîna

correlation. Biasanya syarat minimum yang dapat memenuhi syarat adalah jika $r<0,3$. Sehingga apabila ada korelasi dengan skor total kurang dari 0,3, maka butir dalam instrumen tersebut dikatakan tidak valid (Sugiyono: 2006, 267).

Tabel 10

\begin{tabular}{lccc}
\hline Variabel & Pearson Corelation & $\begin{array}{c}\text { Significant } \\
(2-\text { Tailed })\end{array}$ & Kesimpulan \\
\hline Budaya & $.803^{* *}$ & 0.000 & valid \\
Psikologis & $.504^{* *}$ & 0.000 & valid \\
Pelayanan & $.778^{* *}$ & 0.000 & $\begin{array}{c}\text { valid } \\
\text { valid }\end{array}$ \\
Promosi & $.401^{* *}$ & 0.000 & valid \\
Peng. Tentang produk & $.565^{* *}$ & 0.000 & \\
b. Hasil Uji Reliabilitas & & & \\
& Suatu konstruk atau variabel dikatakan & reliabel jika nilai Cronbach \\
& Alpha $>$ 0,6 (Ghozali, Imam: 2001, 42) & \\
&
\end{tabular}

Reliability Statistics

\begin{tabular}{|r|r|l|}
\hline & $\begin{array}{c}\text { Cronbach's Alpha } \\
\text { Based on } \\
\text { Cronbach's Alpha }\end{array}$ & N of Items \\
\hline .911 & .911 & 49 \\
\hline
\end{tabular}

Dari tabel 11 diatas nilai Cronbach Alpha sebesar 0,911>0,6 maka dapat disimpulkan bahwa variabel tersebut adalah valid dan reliabel untuk mengukur pengaruh budaya, psikologis, pelayanan, promosi, pengetahuan tentang produk terhadap keputusan nasabah dalam memilih bank syari'ah.

3. Hasil Uji Asumsi Klasik

Uji Asumsi Klasik dilakukan untuk mengetahui apakah model regressi yang dibuat dapat digunakan sebagai alat prediksi yang baik. Uji Asumsi Klasik yang akan dilakuka adalah uji multikolinearitas dan uji heterokedastisitas

a. Hasil Uji Multikolinearitas

Pengujian multikolinearitas bertujuan untuk menguji ada tidaknya korelasi yang signifikan yang mendekati sempurna antar variabel independen. Jika antar sesama variabel independen terdapat korelasi yang signifikan, maka pada model regressi linear tersebut terdapat gejala multikolinearitas. 
Ida Nurlaeli

\begin{tabular}{|c|c|c|c|c|c|c|c|c|}
\hline \multicolumn{9}{|c|}{ Coefficients $^{\mathrm{a}}$} \\
\hline \multirow{2}{*}{\multicolumn{2}{|c|}{ Model }} & \multicolumn{2}{|c|}{$\begin{array}{c}\text { Unstandardized } \\
\text { Coefficients }\end{array}$} & \multirow{2}{*}{$\begin{array}{c}\text { Standardized } \\
\text { Coefficients } \\
\text { Beta }\end{array}$} & \multirow[t]{2}{*}{$\mathrm{t}$} & \multirow[t]{2}{*}{ Sig. } & \multicolumn{2}{|c|}{$\begin{array}{c}\text { Collinearity } \\
\text { Statistics }\end{array}$} \\
\hline & & B & Std. Error & & & & Tolerance & VIF \\
\hline 1 & (Constant) & 20.068 & 4.019 & & 4.993 & .000 & & \\
\hline & nilai_Bud & -.108 & .113 & -.089 & -.960 & .339 & .693 & 1.44 \\
\hline & nilai_Psi & .194 & .175 & .099 & 1.111 & .269 & .759 & 1.31 \\
\hline & nilai_Plyn & .548 & .154 & .307 & 3.558 & .001 & .806 & 1.24 \\
\hline & nilai_Prmsi & .685 & .177 & .356 & 3.861 & .000 & .707 & 1.41 \\
\hline & nilai_Peng & .207 & .096 & .209 & 2.168 & .033 & .644 & 1.55 \\
\hline
\end{tabular}

a. Dependent Variable: nilai_Keptsn

Berdasar hasil pengujian multikolinearitas, hasil perhitungan nilai tolerance juga terlihat bahwa tidak ada variabel independen yang memiliki nilai tolerance $<0,10$. Demikian juga dengan hasil perhitungan nilai VIF, dari variabel independen yang diuji tidak ada nilai VIF yang lebih dari 10, maka dapat disimpulkan bahwa tidak ada multikolinearitas antara variabel independen dalam model regresi

b. Uji Heterokedastisitas

Salah satu asumsi penting dari model regresi linear klasik adalah bahwa variance dari residual yang muncul dalam fungsi regresi adalah homokedastisitas, yaitu terjadi kesamaan variance dari residual satu pengamatan ke pengamatan yang lain. Untuk mendeteksi ada atau tidaknya heterokedastisitas dilakukan uji Gletser dengan melihat tingkat signifikansi dari hasil regresi nilai absolute residual sebagai variabel terikat dengan variabel karakteristiknya. Model regresi yang baik adalah yang homoskedastisitas atau tidak terjadi heteroskedastisitas. Deteksi ada atau tidaknya heteroskedastisitas dapat juga dilakukan dengan melihat ada tidaknya pola tertentu (bergelombang, melebar kemudian menyempit) pada grafik ploy (scatterplot) antara nilai prediksi variabel terkait (ZPRED) dengan residualnya (ZRESID) 
Gambar 3.

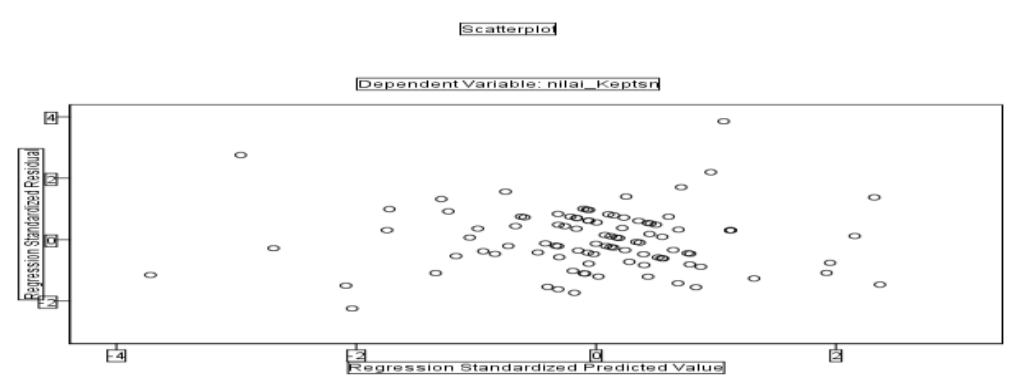

Hasil grafik Scatterplot yang tersaji memperlihatkan bahwa titik-titik menyebar secara acak serta tersebar di atas maupun di bawah angka 0 pada sumbu $y$, serta tidak mempunyai pola yang jelas atau tidak membentuk suatu pola. Untuk itu dapat disimpulkan bahwa tidak terjadi heteroskedastisitas pada model regresi, sehingga model regresi layak digunakan sebagai alat prediksi.

4. Hasil Uji Hipotesis

a. Hasil Uji $\boldsymbol{R}^{\mathbf{2}}$ (koefisien determinasi)

Uji koefisien determinasi digunakan untuk mengetahui seberapa besar variabel independen menjelaskan variabel dependen.

Tabel 13.

Model Summary

\begin{tabular}{llrrr}
\hline Model & $\mathrm{R}$ & R Square & $\begin{array}{c}\text { Adjusted R } \\
\text { Square }\end{array}$ & Std. Error of the Estimate \\
\hline 1 & $.678^{\mathrm{a}}$ & .460 & .431 & 2.80007 \\
\hline
\end{tabular}

a. Predictors: (Constant), Pengetahuan, Psikologi, Pelayanan, Budaya, Promosi

b. Dependent Variable: Keputusan

Koevisien determinasi pada intinya mengukur seberapa jauh kemampuan model dalam menerangkan variasi variabel independen. Nilai koevisien determinasi adalah anatara 0 dan 1 . Nilai $R^{2}$ yang kecil berarti kemampuan variabel independen dalam menjelaskan variasi variabel dependen amat terbatas. Nilai yang mendekati 1 berarti variabel independen memberikan hampir semua informasi yang dibutuhkan untuk memprediksi variasi variabel dependen. (Ghozali, 2011: 97). Dari tampilan output SPSS dari tabel 13 diatas model summary besarnya Adjusted $R$ Square adalah 0,431, hal ini berarti 43,1\% variasi keputusan nasabah memilih bank syariah dapat dijelaskan oleh variasi dari kelima variabel independen (budaya, psikologi, pelayanan, promosi, 
pengetahuan). Sedangkan sisanya $(100 \%-43,1 \%=56,9 \%)$ dijelaskan oleh faktor lain diluar model.

b. Hasil Uji F

Uji statistik $\mathrm{F}$ digunakan untuk menguji apakah semua variabel independen atau bebas yang dimaksud dalam model mempunyai pengaruh secara bersama-sama terhadap variabel dependen atau terkait.Uji $\mathrm{F}$ digunakan untuk menguji kelayakan model penelitian (Ghozali, 2013).

Tabel 14

ANOVA $^{b}$

\begin{tabular}{llrrrrrr}
\hline Model & & $\begin{array}{c}\text { Sum of } \\
\text { Squares }\end{array}$ & Df & $\begin{array}{c}\text { Mean } \\
\text { Square }\end{array}$ & F & Sig. \\
\hline $\mathbf{1}$ & Regressi & 628.041 & 5 & 125.608 & 16.02 & $.000^{\mathrm{a}}$ \\
& on & & & & 1 & & \\
& $\begin{array}{l}\text { Residual } \\
\text { Total }\end{array}$ & 736.999 & 94 & 7.840 & & & \\
& 1365.040 & 99 & & &
\end{tabular}

a. Predictors: (Constant), Pengetahuan, Psikologi, Pelayanan, Budaya, Promosi

b. b. Dependent Variable: Keputusan

Dari tabel 14 diatas dapat diketahui dalam model ANOVA dapat diperoleh $F_{\text {hitung }}$ sebesar 125.608. Dengan demikian tingkat signifikan sebesar 0.05 dan $\mathrm{d} f_{1}=\mathrm{k}-1$, dimana $(\mathrm{k})$ adalah jumlah variabel bebas+terikat, dan $\mathrm{d} f_{2}=$ $\mathrm{n}-\mathrm{k}$ dimana (n) adalah jumlah sampel dan (k) adalah jumlah variabel bebas+terikat maka $: \mathrm{d} f_{1}=\mathrm{k}-1=6-1=5, \mathrm{~d} f_{2}=\mathrm{n}-\mathrm{k}=100-6=94$

Maka didapat nilai $F_{\text {tabel }}=2.31$.Karena $F_{\text {hitung }}(16.021)>F_{\text {tabel }}(2.31)$ Jadi, dapat disimpulkan bahwa faktor budaya, psikologi, pelayanan, promosi, pengetahuan tentang produk secara bersama-sama berpengaruh signifikan memberikan kontribusi yang terhadap keputusan nasabah dalam memilih bank syariah. Sehingga model regresi yang didapatkan layak digunakan untuk memprediksi, maka dapat disimpulkan bahwa $H_{0}$ di tolak dan $H_{1}$ diterima. Dari hasil tabel regresi di atas, juga dapat disimpulkan bahwa variabel independen yang paling dominan atau yang paling besar pengaruhnya terhadap variabel dependen adalah variabel promosi (X4). Dikarenakan nilai koefisien regresinya paling tinggi yaitu 0,705. Yang artinya yaitu apabila nilai promosi meningkat satu satuan unit maka nilai kepuasan nasabah dalam memilih bank syariah juga akan meningkat sebesar 0,705 . 


\section{Islãmadîna \\ JURNAL PEMIKIRAN ISLAM}

Model yang digunakan untuk mengetahui pengaruh variabel independen yaitu faktor budaya, psikologi, pelayanan, promosi, pengetahuan tentang produk terhadap variabel dependen yaitu yaitu keputusan memilih bank syariah adalah model regresi linier berganda. Berikut ini adalah tabel hasil pengujian analisis regresi linier berganda:

Tabel 15.

Coefficients $^{\mathrm{a}}$

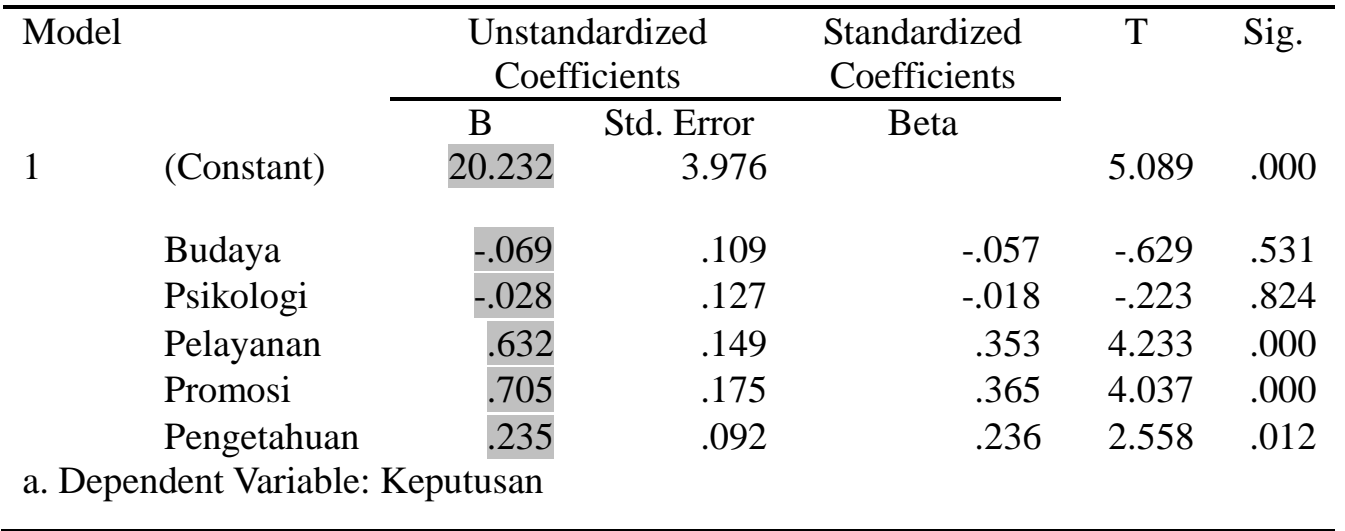

Dari hasil table 15 diatas, dapat diketahui bahwa persamaan regresi linier berganda dapat dirumuskan pada penelitian ini adalah sebagai berikut :

Y (keputusan $)=20.232-0,069$ Budaya $-0,028$ Psikologi + 0,632 Pelayanan $+0,705$ Promosi $+0,235$ Pengetahuan $+\mathrm{e}$

Interpretasi dari persamaan tersebut adalah sebagai berikut :

$\alpha \quad=$ Konstanta menunjukkan angka 20.232, berarti jika nilai independen dengan nilai budaya (X1), psikologi (X2), pelayanan (X3), promosi (X4) dan pengetahuan (X5) bernilai konstan maka variabel dependen yaitu keputusan nasabah memilih bank syariah meningkat 20.232 .

$\mathrm{X} 1$ budaya $=$ Nilai koefisien regresi budaya adalah sebesar $-0,069$, menunjukkan jika variabel independen dengan nilai budaya (X1) berpengaruh secara negatif. Yang artinya yaitu apabila nilai budaya turun $1 \%$ maka nilai keputusan nasabah memilih bank syariah juga akan meningkat sebesar-0,069.

$\mathrm{X} 2$ psikologi $=$ Nilai koefisien regresi psikologi adalah sebesar $-0,028$, 
menunjukkan jika variabel independen dengan nilai psikologi (X2) berpengaruh secara negatif. Yang artinya yaitu apabila nilai psikologi turun $1 \%$ maka nilai keputusan nasabah memilih bank syariah juga akan meningkat sebesar-0,028.

$\mathrm{X} 3$ pelayanan $=$ Nilai koefisien regresi pelayanan adalah sebesar 0,632, menunjukkan jika variabel independen dengan nilai pelayanan (X3) berpengaruh secara positif. Yang artinya yaitu apabila nilai pelayanan naik $1 \%$ maka nilai keputusan nasabah memilih bank syariah juga akan meningkat sebesar 0,632 .

$\mathrm{X} 4$ promosi $=$ Nilai koefisien regresi promosi adalah sebesar0,705, menunjukkan jika variabel independen dengan nilai promosi (X4) berpengaruh secara positif. Yang artinya yaitu apabila nilai promosi naik $1 \%$ maka nilai keputusan nasabah memilih bank syariah juga akan meningkat sebesar 0,705 .

X5 pengetahuan= Nilai koefisien regresi pengetahuan adalah sebesar 0,235, menunjukkan jika variabel independen dengan nilai pengetahuan (X5) berpengaruh secara positif. Yang artinya yaitu apabila nilai pengetahuan naik $1 \%$ maka nilai keputusan nasabah memilih bank syariah juga akan meningkat sebesar 0,235 .

c. Hasil Uji t

Uji t (parsial) dilakukan untuk mengetahui tingkat signifikansi pengaruh masing-masing variabel independen terhadap variabel dependen secara parsial.

Dilihat dari hasil uji statistis pada tabel 15. regresi diatas, dapat diketahui bahwa ada tiga variabel yang nilai signifikannya dibawah 0.05 , yaitu variabel dengan nilai pelayanan, promosi dan pengetahuan tentang produk. Hal ini menunjukkan bahwa ketiga variabel tersebut berpengaruh signifikan terhadap keputusan nasabah dalam memilih bank syariah.

Lebih jelasnya, hasil uji tersebut sebagai berikut:

1) Menguji signifikasi variabel budaya

Dilihat dari data print out di atas tingkat signifikan untuk variabel budaya sebesar $0,531>0,05$. Hal ini berarti bahwa $H_{0}$ diterima dan 


\section{Islãmadîna \\ JURNAL PEMIKIRAN ISLAM}

$H_{1}$ ditolak, artinya variabel budaya secara parsial tidak berpengaruh nyata terhadap keputusan nasabah memilih bank syariah.

2) Menguji signifikasi variabel psikologi

Variabel psikologidengan tingkat signifikasinya $0,824>0,05$. Dengan demikian $H_{0}$ diterima $H_{1}$ ditolak. Yang berarti variabel psikologis secara parsial tidak berpengaruh nyata terhadap keputusan nasabah memilih bank syariah.

3) Menguji signifikasi variabel pelayanan

Variabel pelayanandengan tingkat signifikasin $0,000<0,05$. Dengan demikian $H_{0}$ ditolak $H_{1}$ diterima.Yang berarti variabel pelayanan secara parsial berpengaruh positif terhadap keputusan nasabah dalam memilih bank syariah.

4) Menguji signifikasi promosi

Variabel promosi dengan tingkat signifikasi $0,000<0,05$. Dengan demikian $H_{0}$ ditolak $H_{1}$ diterima. Yang berarti variabel promosi secara parsial berpengaruh posotif terhdap keputusan nasabah dalam memilih bank syariah.

5) Menguji signifikasi pengetahuan

Variabel pengetahuan dengan tingkat signifikasi $0,012<0,05$. Dengan demikian $H_{0}$ ditolak $H_{1}$ diterima.Yang berarti variabel pengetahuan secara parsial berpengaruh positif terhadap keputusan nasabah memilih bank syariah.

\section{PEMBAHASAN}

Faktor budaya merupakan faktor yang berpengaruh negatif terhadap keputusan nasabah dalam memilih bank syariah, karena kebudayaan merupakan faktor yang paling luas sehingga pemasar dituntut harus memahami peran yang dimainkan kultur, sub-kultur dan kelas sosial. Jika dilihat dari hasil kuesioner yang telah disebarkan menunjukan hasil bahwa nasabah memilih BPRS bukan karena sesuai dengan ajaran islam, tetapi karena kebutuhan dan transaksi yang menguntungkan. Memilih BPRS karena persepsi tentang bunga bank haram juga tidak mempengaruhi nasabah, karena nasabah percaya bahwa menggunakan jasa bank syariah menguntungkan. Faktor psikologis tidak berpengaruh signifikan terhadap keputusan nasabah dalam memilih bank syariah. Beberapa alasan yang mendukung hal ini bahwa faktor psikologis 
terdiri dari pengalaman belajar dan motivasi. Teori pembelajaran yang dikembangkan oleh Paslov, Skinner dan Hull menyatakan perilaku seseorang merupakan hasil belajar dari akumulasi pengalaman selama hidupnya. Nasabah BPRS didominasi oleh pendidikan tingkat menengah yang masih kurang dari sisi informasi dan keilmuan tentang ekonomi islam. Motivasi menurut Freud bahwa kadang seseorang tidak bisa memahami motivasi yang mendorong perilakunya secara pasti dan menurut Maslow bahwa motivasi seseorang dapat dihubungkan dengan kebutuhannya, maka meskipun nasabah mengetahui sedikit tentang budaya atau keilmuan ekonomi islam, hal itu tidak cukup untuk menjadi pengaruh positif ketika tidak diiringi dengan faktor yang tepat berkaitan dengan kebutuhan nasabah.

Faktor pelayanan merupakan faktor yang berpengaruh positif signifikan terhadap keputusan nasabah dalam memilih bank syariah. Menurut Moenir seseorang sangat memerlukan pelayanan baik dari diri sendiri maupun orang lain, apapun tidak terlepas dari unsur jasa atau layanan, baik itu jasa sebagai produk maupun jasa sebagai pelengkap. Faktor pelayanan merupakan faktor yang dapat langsung dirasakan oleh nasabah dan mempengaruhi nasabah dalam bertransaksi dengan bank syariah artinya jika pelayanan yang baik meningkat maka pengambilan keputusan nasabah untuk menabung atau menggunakan jasa lain akan meningkat (Efendi, Lutfi 2009). Bahkan menurut penelitian yang diketuai oleh Dr. Hanif Amali Rifai bahwa faktor keagamaan tidak akan berpengaruh terhadap keputusan nasabah dalam memilih bank syari'ah kecuali diiringi dengan faktor pelayanan berupa keramahan dari petugas serta persepsi bahwa berurusan dengan bank syari'ah lebih cepat dan mudah. Faktor promosi merupakan faktor yang mempengaruhi nasabah dalam memilih bank syariah. Menurut Pavlov, Skinner dan Hull nasabah merupakan konsumen/manusia yang selalu belajar dari pengalamannya, maka menciptakan komunikasi informal (word-of-mouth communication) menjadi kewajiban pemasar. Hal ini sudah dilakukan oleh pemasar BPRS dimana target audience promosi bukan lagi bersifat masal tetapi user. Dilihat dari target frekuensi pembelian juga bukan hanya sekali tetapi berulang dengan sarana multimedia dengan cara membina relationship.

Pengetahuan tentang produk merupakan faktor yang berpengaruh signifikan terhadap keputusan nasabah dalam memilih bank syariah. Menurut penelitian yang diketuai oleh Dr. Hanif Amali Rifai bahwa variasi produk yang ditawarkan bukan merupakan pertimbangan utama, hal ini mengindikasikan bahwa nasabah bank syari'ah cenderung melihat produk bank bukanlah sesuatu yang "unik" tetapi menyerupai produk komoditas lainnya. Hal ini dapat disebabkan karena 


\section{Islãmadìna \\ JURNAL PEMIKIRAN ISLAM}

kurangnya pemahaman nasabah akan produk yang ditawarkan. Dalam penelitian Echa Saefullah Hermansyah bahwa tanggapan responden mengenai pengetahuan konsumen dengan rata-rata skor bernilai 328 dan keputusan nasabah memilih perbankan syariah berada dengan rata-rata skor bernilai 332 . Dan kedua rata-rata skor tersebut berada pada kategori baik. Maka BPRS selalu semaksimal mungkin mensosialisasikan jenis produk dan operasionalnya, sehingga masyarakat paham dan tertarik, meskipun pengambilan keputusan selanjutnya adalah memilih produk yang sesuai dengan kebutuhan, namun pengetahuan tentang produk seperti jenis, operasional dan kesyar'iannya tetap menjadi pengaruh pertimbangan nasabah.

\section{KESIMPULAN}

Berdasarkan hasil penelitian dan pembahasan maka diperoleh kesimpulan sebagai berikut:

1. Bahwa faktor budaya sebesar $0,531>0,05$. Hal ini berarti bahwa $H_{0}$ diterima dan $H_{1}$ ditolak, artinya variabel budaya secara parsial tidak berpengaruh terhadap keputusan nasabah memilih bank syariah.

2. Bahwa faktor psikologi dengan tingkat signifikasinya $0,824>0,05$. Hal ini berarti bahwa $H_{0}$ diterima $H_{1}$ ditolak, bahwa variabel psikologis secara parsial tidak berpengaruh terhadap keputusan nasabah memilih bank syariah.

3. Bahwa faktor pelayanan dengan tingkat signifikasin $0,000<0,05$. Hal ini berarti bahwa $H_{0}$ ditolak $H_{1}$ diterima, bahwa variabel pelayanan secara parsial berpengaruh positif terhadap keputusan nasabah dalam memilih bank syariah.

4. Bahwa faktor promosi dengan tingkat signifikasi $0,000<0,05$. Hal ini berarti bahwa $H_{0}$ ditolak $H_{1}$ diterima, bahwa variabel promosi secara parsial berpengaruh positif terhdap keputusan nasabah dalam memilih bank syariah.

5. Bahwa faktor pengetahuan tentang produk dengan tingkat signifikasi $0,012<$ 0,05. Hal ini berarti bahwa $H_{0}$ ditolak $H_{1}$ diterima, bahwa variabel pengetahuan secara parsial berpengaruh positif terhadap keputusan nasabah memilih bank syariah.

6. Hasil pengujian menunjukan bahwa variabel pelayanan, promosi, dan pengetahuan secara bersama-sama atau simultan mempengaruhi keputusan nasabah dalam memilih bank syariah. Sedangkan variabel budaya, psikologis tidak mempengaruhi keputusan nasabah dalam memilih bank syariah.

7. Hasil uji regresi linear berganda menunjukan bahwa variabel promosi merupakan variabel yang paling dominan yang mempengaruhi keputusan nasabah dalam memilih bank syariah. 


\section{DAFTAR PUSTAKA}

Abdullah, Taufik, dan M. Rusli Karim, ed., Metodologi Penelitian Agama: Sebuah Pengantar, Yogyakarta, Tiara Wacana, 1989.

Agung Nugroho, Bhuono, Strategi Jitu Memilih Metode Statistik Penelitian dengan SPSS, Yogyakarta, 2005.

Amin, A Riawan, Seminar: Prospek dan Tantangan Perbankan Syari'ah di Era Ekonomi Global, Balai Tawangarum Sabtu 14 Mei 2011.

Ancok, Djamaluddin, Fuad Nashori Suroso, Psikologi Islam, Yogyakarta, Pustaka Pelajar, 1995.

Antonio Syafi'i, Muhammad, Bank syariah Dari Teori Ke praktek, Jakarta, Gema Insani, 2001.

Arifin, Syamsul, Islam Indonesia (Sinergi Membangun Civil Islam dalam Bingkai Keadaban Demokrasi), Malang, Universitas Muhammadiyah Malang Press, 2003.

Assauri, Sofjan, Manajemen Pemasaran Dasar Konsep dan Strategi, Raja grafindo persada, Jakarta, 2011.

Dixon, Rob “Islamic Banking”, International Journal of Bank Marketing 10.6, Ilmu semesta,Cet.I, 2003.

Engel, James F, et al, Perilaku Konsumen, Jakarta, Binapura Aksara, 1994.

Glock, Charles Young, and Rodney Stark, Religion and Society in tension, Chicago, Rand McNally, 1965.

Ghozali, Maski, Analisis Keputusan Nasabah Menabung: Pendekatan Komponen dan Model Logistik Studi Pada Bank Syari'ah di Malang, Journal of Indonesian Applied Economics, Volume 4 Nomor 1 Mei 2010 .

Gozali, Imam, Aplikasi Multivariate dengan Program SPSS, Semarang, Badan Penerbit Universitas Diponegoro, 2006.

Gozali, Imam, Aplikasi Analisis Multivariate Dengan Program IBM SPSS 19. Semarang: Badan penerbit Universitas Diponegoro, 2011.

Guspul, Ahmad, Kualitas Pelayanan, Kepuasan dan Kepercayaan Nasabah pada Koperasi Jasa Keuangan Syari'ah di Wonosobo, Jurnal PPKM III (2014) 156-170, ISSN: 2354-869X.

Hanif, Amali Rifai, dkk, Identifikasi Faktor Penentu Keputusan Konsumen dalam Memilih Jasa Perbankan: Bank Syari'ah vs Bank Konvensional, Kerjasama Bank Indonesia dan Center of Banking Research, Universitas Andalas. 


\section{Islãmadîna \\ JURNAL PEMIKIRAN ISLAM}

Hasan, Iqbal, Analisis Data Penelitianb Dengan Statistik, Jakarta, Bumi Aksara, 2004.

Hermansyah, Echa Saefullah, Pengaruh Pengetahuan Konsumen terhadap Keputusan Memilih Perbankan Syari'ah (Studi Kasus pada Bank Syariah Mandiri KCP Bekasi, Kalimalang), Universitas Guna Darma.

Ifham, Ahmad, Pedoman Umum Lembaga Keuangan Syari'ah, Jakarta, PT. Gramedia Pustaka Utama, 2010.

Kamal Zubair, Muhammad, Akselerasi Pertumbuhan Bank Syari'ah di Indonesia, Millah Vol. Vm, No. /, Agustus 2008.

Latifa M. Algaoud, Mervyn K.Lewis, Islamic Banking, terbitan Edward Elgar, Massachussetts, Diterjemahkan oleh Burhan Wirasubrata, Jakarta: Serambi, 2001.

Leon, G. Schiffman and Lesli Lazar Kanuk, Consumer Behaviour, Enggleword Cliffs, NJ: Prebtice Hall, 2004.

Maisya, Fitri, Pengaruh Periklanan, Promosi Penjualan dan Hubungan Masyarakat terhadap Keputusan Menabung di PT Bank Negara Indonesia, Tbk. Cabang Bukuttinggi.

Maski, Ghozali, Analisis Keputusan Nasabah Menabung: Pendekatan Komponen dan Model Logistik Studi pada Bank Syari'ah di Malang, Journal of Indonesian Applied Economics Vol. 4 No. 1 Mei 2010.

Marimin, Teknik dan Aplikasi Pengambilan Keputusan Criteria Majemuk, Jakarta, PT Grasindo anggota IKAPI, 2004.

Maysarah, Damayanti, Analisis Faktor-faktor yang Mempengaruhi Keputusan Nasabah dalam Memilih Bank Syari’ah, 2014.

Michiels, Ananda, 2013, Pengetahuan Konsumen, https://anandarfm.wordpress.com/2013/11/25/pengetahuan-konsumen-c onsumer-knowledge/ (diakses tanggal 15 Mei 2017).

Miniard, Paul W, Blackwell, Roger D, Engel, James F, Perilaku Konsumen Jilid 1 Edisi Keenam, Jakarta, Binarupa Aksara, 1994.

Minor, Mowen/ C. Mowen Jhon, Perilaku Konsumen Jilid 1 Edisi kelima, Jakarta, Erlangga, 2002.

Muchilis, Mustakim, 2013. Faktor-Faktor Yang Mempengarui Nasabah Dalam Memilih Bank Syariah (Bank Syariah VS Bank Konvensional), Jurnal Ekonomi. Manajemen dan Akuntansi Vol.3, No.1, Juni 2013.

Muhammad, Majalah Investor, edisi Oktober 2008.

Muhammad, Manajemen Bank Syari'ah, Yogyakarta, Ekonisia, 2002.

Muladi, Wibowo, Pengaruh Faktor Sistem Bagi Hasil, Persyaratan Administrasi, Kualitas Pelayanan, Sistem Operasional Syari'ah dan Promosi terhadap 
Keputusan Nasabah, Jurnal Dinamika Manajemen Vol. 1 No. 12010.

Mutasowifin, Ali, "Menggagas Strategi Pengembangan Perbankan Syari'ah di Pasar Non Muslim” Jurnal Universitas Paramadina 3.1, 2003.

Prabu Mangkunegara, Anwar, Perilaku Konsumen Edisi Revisi, Bandung, Refika Aditama, 2002.

Prasetyo, Bambang dan Lina Miftahul Janah, Metodologi Penelitian Kuantitatif, Jakarta, Raja Grafindo Persada, 2006.

Priyanto, Dwi, Paham Analisis Data Dengan SPSS, Yogyakarta, Mediakson, 2011.

Qardhawi, Yusuf, Peran Nilai dan Moral dalam Perekonomian Islam, Jakarta, Robbani Perss, 1997.

Rangkuti, Freddy, Strategi Promosi yang Kreatif \& Analisis Kasus Integrated Marketing Communication, Jakarta, PT Gramedia Pustaka Utama, 2009.

Ratnawati, Anny, "Potensi dan Strategi Pengembangan Bank Syariah di Indonesia", JHI, volume 9, nomor 2, 2012.

Ridwan, Engkos Achmad Kuncoro, Cara Menggunakan dan Memakai Analisis Jalur (Path Analiysis), Bandung, Alfabeta, 2008.

Setiadi, Nugroho J, Perilaku Konsumen : Perspektif Kontemporer Pada Motif, Tujuan Dan Keinginan Konsumen, Jakarta : Kencana, 2010.

Simamora, Bilson, Panduan Riset Perilaku Konsumen, Jakarta, PT Gramedia Pustaka Utama, cet ke 3 ISBN 978-979-22-0106-8, 2008.

Soemitra, Andri, Bank Dan Lembaga Keuangan Syariah, Jakarta, Kencana, 2009.

Stark, Rodney, and Charles Y Glock, American Piety: The Nature of Religious Commitment, Vol 1 Univ of California Press, 1968.

Sugiyono, Metode Penelitian Kuantitatif Kualitatif Dan R\&D, Bandung, Alfabeta, 2009.

, Metode Penelitian Kombinasi (Mixed Methods), Bandung, Alfabeta, 2012

Metode Penelitian Kuantitatif, Kualitatif, Dan R\&D, Bandung, Alfabeta, 2013.

, Metode Penelitian Kombinasi (Mixed Methods), Bandung, Alfabeta, 2014

Tanireja, Tukiran dan Mustafidah, Hidayat, Penelitian Kuantitatif (Sebuah Pengantar), Bandung, Alfabeta, 2011.

Tjiptono, Fandy, Strategi Pemasaran Edisi Tiga, Yogyakarta, CV. Andi Offset, 2008 


\section{Islãmadîna \\ JURNAL PEMIKIRAN ISLAM}

Volume XVIII, No. 2, Juni 2017 : 75-106

Umar, Husein, Riset Sumber Daya Manusia Dalam Organisasi, Jakarta, Gramedia Pustaka Utama, 1997.

Riset Pemasaran dan Perilaku Konsumen, Jakarta, PT Gramedia Pustaka Utama, 2000.

Umam, Khotibul, Trend pembentukan Bank Umum Syari'ah Pasca UndangUndang Nomor 21 Tahun 2008 (Konsep, Regulasi, dan Implementasi), Yogyakarta, BPFE Yogayakrta, 2009.

Visser, Wayne AM, and Alastair Macintosh, "A Short Review of The Historical Critique of Usuary" Accounting Business \& Financial History 8.2, 1998.

Yulaifah, Atin, Pengaruh Budaya, Sosial, Pribadi dan Psikologi terhadap Keputusan Nasabah dalam Memilih Bank Syari'ah, 2011.

Abdurrahman M, Islam Aboge: Harmoni Islam dan Tradisi Jawa, Dosen STAI Al-Hidayah Bogor, Senin 28 Mei 2012.

Pandu Wicaksono, Strategi Adaptasi Penganut Aliran Aboge dalam Menjaga Toleransi Keagamaan di Desa Onje Kecamatan Mrebet Kabupaten Purbalingga, FKIP PGRI Yogyakarta. 